\title{
PEMANTAUAN PAPARAN RADIASI LINGKUNGAN TERPADU DENGAN KOMUNIKASI GSM/GPRS
}

\author{
Ikhsan Shobari ${ }^{1}$, Risanuri Hidayat ${ }^{2}$, Sujoko Sumaryono ${ }^{3}$ \\ 'Mahasiswa Pascasarjana Jurusan Teknik Elektro dan Teknologi Informasi UGM \\ ${ }^{2,3}$ Dosen Jurusan Teknik Elektro dan Teknologi Informasi UGM \\ I1. Grafika No 2, Yogyakarta, 55281. \\ Email: 'ishobary@gmail.com, risanuri@jteti.gadjahmada.edu, ${ }^{3}$ sujoko@amti.ugm.ac.id
}

\begin{abstract}
ABSTRAK
PEMANTAUAN PAPARAN RADIASI LINGKUNGAN TERPADU DENGAN

KOMUNIKASI GSM/GPRS. Penjaminan pengoperasian reaktor yang tidak membahayakan pekerja dan masyarakat sangat penting untuk dilakukar Untuk tu perlu dilakukan pernantauan paparan radiasi dan lingkungan secar terus menerus. Perkembangan teknologi informasi dan komunikasi terkuri memungkinkan dilakukaw pengukuran paparan radiasi dan lingkungan terpadu secara jarak jauh, on-line dan real time. Paper ini memperkenalkan dan membahás rancang bangun sistem pementauan paparan radiasi lingkungan terpadu dengan memanfaatkan teknologi informasi dan komunikasi, Data berupa paparan radiasi, suhu, arah angin. Kécepatan angin dan, curah hujan, dikirim secara periodis dengan memantatkan teknologi GSM/GPRS. Modui Arduino yang berbasis mikrokontroller AT Mega 328, digunakan untuk akuisi data dari kolima sersor tersebut, untuk seiunjutnya melalui shield GSM/GPRS data dikirim ke komputer infortnasi proses melalui pesan singkat SMS. Data yang diterima ditampilkan dalan komputer dalam bentuk tabel dan dapat diolah dengan perangkat lunak lainnya. Hasil menunjukan bahwa sistem yang dibangun berhasil diimplemantasikan untuk penantauan paparan radiusi lingikungan terpadu secara on-line dan real time untuk pernantauan jarak jauh. Rerata kesalahan pembacaan setelih dilakukan kalibrasi adalah 6,34 persen.
\end{abstract}

Kata Kunei : Monitor Radiasi, lingkungan, mikrokontrolter, komunikasi GSM/GPR.

\section{ABSTRACT}

INTEGRITED ENUTRONMENTAL MONITORING OF RADLATION EXPOSURE WITH GSM/GPRS COMMUNICATION. Assurance that the reactor operation dees tor endanger worters and the cannumity is wey inportant to da It is mecessary for manitoring environmental radiation enpasure and contimages secar. The development of infonmation and conmunication teclmology enables current

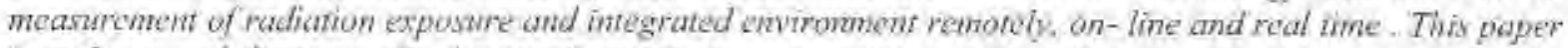
introduces and discusces the design of monitoring system integrated envirunmental radiation erposure by uttilizing information omel comminication reclunologies. Data suck as exposure to radiation temperature. wind direction, wind speed and rainfall, sent periadically by utilizing GSM/GPRS. Andune-based microcontroller module AT Mega 328, is used for the data acquasition of the fith sensor, to further shield via GSM GPRS Jata is sen to a computer processes infumation tia SMS texi message. The data received is shown in the computer in the form of lables and can be proceswed by other softurare Results showed that the systcm successfully dimplemantasikan for imegrated envinomental monitoring of radiation exposure on-

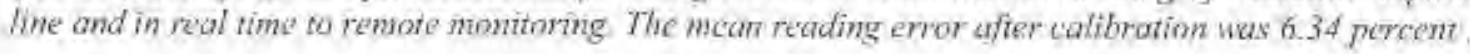

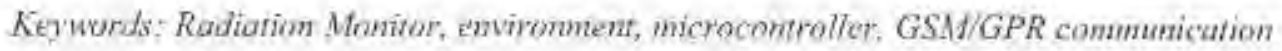




\section{PENDAHULUAN}

Indonesia sast ini mengaperasikan liga reaktor nuklir untuk keperluan riset, Reaktor Kartini di Yogyakarta, Reaktor Triga 2000, di Bandung dan Reaktor GA Simabessy di Kawasan Puspiptek Serpong. Penjaminan pengoperasian reaktor-reaktor tersebut yang tidak membahayakan pekerja dan masyarakat sangat penting untuk dilakukan. Untuk itu perlu dilakukan pemantauan paparati radiasi dan lingkungan secar terus menerus sampai pada radius tertentu sekurangnya $5 \mathrm{~km}|1| 2|3|$.

Perkembangan teknologi informasi dan komunikasi saat ini sangat mendukung untuk di lakukan pengukuran paparan radiasi dan lingkungn terpadu secara remote - on-line dan real time. Pemanfaatan teknologi dengan penempatat jaringan sensor nirkabel, selanjutnya disebut Wireless Sensor Network (WSN) atau dengan memanfaatkan wahana tak berawak baik darat ataupun udsa sangatlah memungkinkan. Bebarapa pemakaian dan pemanfautan Wireless Sensor Nefwork (WSN) untuk bidang pertanian, lingkungan, ataupun industri telah banyak digunakin ${ }^{[4||[4 \text { n] }}$.

Beberapa protokol komunikasi dipakai dan dikombinasikan antuk saling melengkapi kekurangan masing-masing pada saat diaplikasikan. Beberapa protokol komunikasi yang dikombinasikan misalnya dari node sensor ke node sensor yang lain mengganakan protokol IEEE 802.15 .4 , selanjutnya dari masing-masing node data dikirim ke lokal server menggunakan protokol IEEE $802.11 \mathrm{a} / \mathrm{b} / \mathrm{g} / \mathrm{n}$ atau wireless $L A N$. Data yang sudah terkumpul di jokal server selanjunya dapat diakses atau ditransmisikan melalut intemet Jengan memanfaatkan modem GSM (Global System for Mobile Communicarions), modern CDMA (Code Division Multiple Access) atas modem ADSL (Assmmetric Digital Subseriber Line), atau komunikasi lainnya yang sudah tersedia ${ }^{[57]}$

Paper ini memperkenalkan dan membahas rancang bangư sistem untuk pengambilan data dalam hal ini data paparan radiasi. dari data cuaca seperti suhu udara, kecepatan angin, arah angin, dan curah hujan. Data dikirim dari litik pemantauat (node) melatui jaringan GSM/GPRS fGlobal System for Mobile Communications)/(General Packet Radio Service) dengan layanan SMS (short masage service) dengan mamanfaatkan modul Arduino dan GSM Shield. Data dikirim secara periodis sctiap selang waktu tertentu. Selanjutnya data diterima melalui modut Arduino dan GSM Shield yang berfungsi sebagai penampung untuk selajutnya dikirim ke komputer proses melalui komunikasi serial. Data dikomputet ditampung dan disimpan dalam bentuk tabel dengan format data berupa file ${ }^{*} \mathrm{CSV}$. Teknologi ini memungkinkan pengukuran paparan radiasi dapat dilakukan secaran on-line dan real time, untuk jarak yang jauh, dan dată dapat ditampilkan lobih cepat. Dengan data yang terus diperbaharui peringatan bila terjadi tingkat paparan radiasi yang melebihi nilai batas ambang segera diketahui, dan dapat secepatnya diberikan peringatan kedaruratan.

\section{Perancangan Sistem}

Sistem pemantauan paparan radiasi terpadu dengan komunikasi GSMGPRS terdiri dari dua bagian utama yaitu pada bagian node' dan bagian komputer proses, seperti ditampilkan pada Gambar 1. Bagian node berfungsi untuk mengumpulkan data dari sensor - sensor, Bagian ini terdiri dari sistem monitor radiasi, sistem sensor cuaca, modal akuisisi dan komunikasi, dan modul catu daya. seperti pada ditunjukan pada Gambar 2 di hawah. Bagian komputer proses berfungsi untuk menerima data yang dikirim dari setiap node untuk selanjutnya data ditampilkan pada komputer. Bagian ini teridiri dari modul akuisisi dan komunikasi serta komputer proses. Gambar 3, menunjukan blok diggram sistem untuk ini.

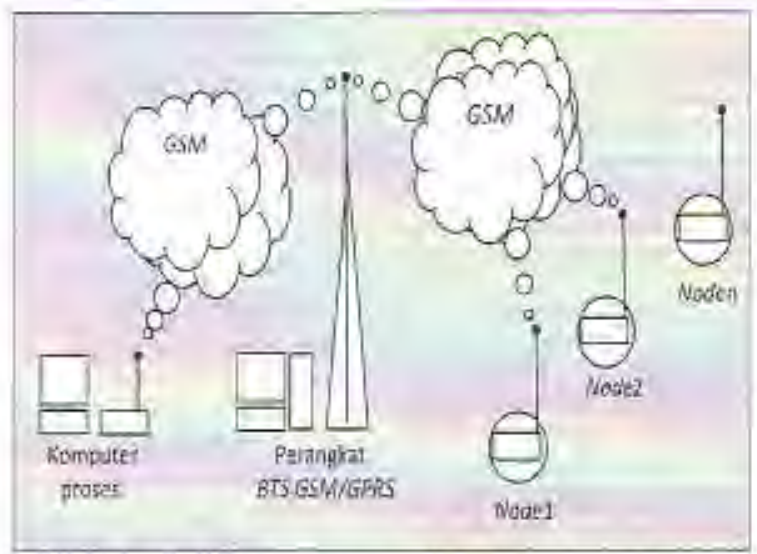

Gambar I. Blok diagram keseluruhan sistem

Pengiriman data melalui SMS dilaknkan untuk selang waktu setiap 2 menit sekali, dengan memanfaatkan Jayanan operaior GSM yang ada. Data dikirim ke komputer proses melalui modul akuisisi dan komunikasi data 
dari sctiap nodo yang ada. Keterbatasán sarana pentinjang membatasi penelitian ini dilakukan pengiriman data hanya dari satu node pengambilan data. Pengiriman data dari node lainnya dapat disimulasikan dan sistem dapat menerima data simulasi yang dikirimkan (lihat Gambar 2 dan 3).

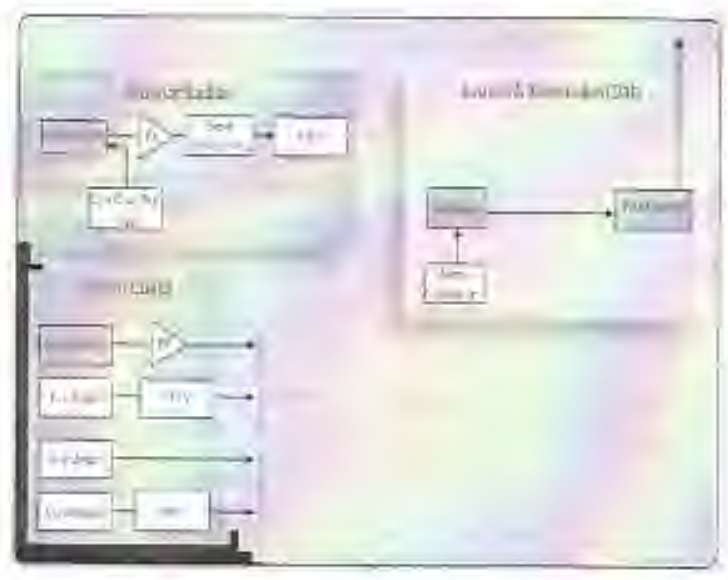

Gambar 2. Blok diagram sistem pada setiap node

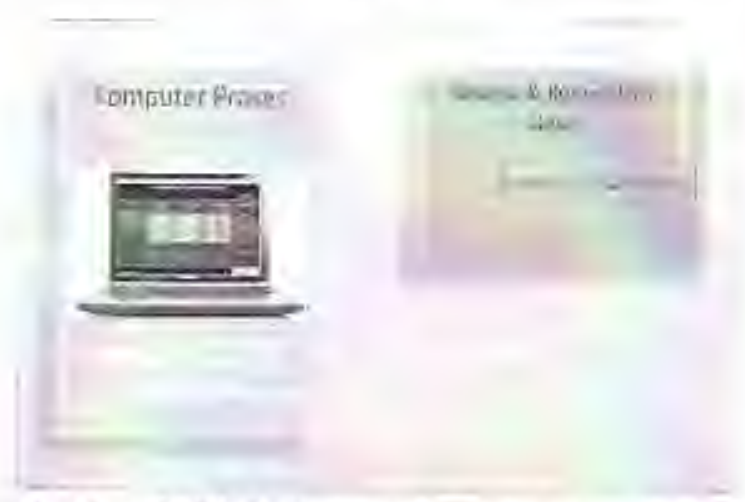

Gambar 3. Blok diagram sistem penerima dan komputer proses

Peralatan yang digunakan dalam perancangan dan pembuatun sistem ini berupa toolset elektronik. Sccopemeter Fluke 192B, Signal Source Calibrator HIOKI 7016. Digital Multimeter Fluke 117. Peralatan untuk pembanding pengukuran berupa lermometer digital, Kompas penunjuk arah, dan surveymeter digital Thermo Scientific FAGG seri FH-40-GL. Peralatan penunjang untuk pembuatan program berupa softhare perangkat Junak Sketch, untuk pembuatan program di modul arduino, dan Gobetwino untuk manajemen pengaturan dan penyimpanan file ke komputer proses. Komputer dengan sistem operasi Microsofi Window Seven.
U/timate Edition, difungsikan untuk pembuatan program dan sebagai komputer proses.

Bahan yang digunakan adalah dua buah Modul Arduino dengan Shield GSM, Sensor Suhu, Detektor Geiger Mueller, Phototransistor: sebagai sensor kecepatan angin, Potensiometer sebagai sensor arah angin, dan switch sebagai simulasi sensor curah hujan. Bahan-bahan elektronik seperti resistor, capasitor, dioda dan transistor, dalam berbagai nilai, beberapa jenis $I C$ CMOS, TTL, $O P A M P$. Tinter counter LM555, Regulator. dioda Led, berbagai jenis conector dan terminal digunakan untuk membangun modulmodul yang diperlukan.

Langkah kerja yang dilakukan setelah peralatan dan bahan tersedia adalah melakukan pembuatan peratigkat keras, instalasi. pembuatan soffware, kalibrasi, dan pengujian.

Sistem monitor radiasi terdiri dari detektor Geiger Mueller tipe Centronic SI$180 \mathrm{G}$, yang dicalu oleh tegangan tinggi $400 \mathrm{~V}$ DC, dan signal conditioning. Keluaran dalam bentuk pulsa tinggi $5 \mathrm{~V}$ yang merepresentasikan banyaknya paparan radiasi yang ditangkap olch detektor. Selanjutnya jumlah pulsa dirubah dalam bentuk tegangan yang merepresentasikan jurnlah pulsa dengan menggunakan rangkaian $F$ to $V$ (Frekwensi to Voltage)

Keluaran berupa tegangan $0-5$ Volt setelah melalui rangkaian rangkaian $F$ to $\mathrm{V}$ (Frekwensi ta Voltage). Keluaran berupa tegangan analog sebagai masukan analog input modul Arduino pori A3. Rangakaian pengubah frekwersi $\mathrm{ke}$ tegangan ( $\mathrm{F}$ to $\mathrm{V}$ ) digumakan. Pengaturan untuk rangkaian $F$ to $V$, maksimal adalah 1600 pulsa untuk 4 vott. yang setara dengan paparan radiasi maksimal sebesar 50 uSvijam yang setara dengan pulsa keluaran detektor 1600 pulsa per detik.

Sensor cuaca terdiri dari sensor suhu, kecepatan angin, sensor arah angin, dan sensor curah hujan. Sensor sulu digunakan LM35. dan sinyalnya dilipatkan dengan dua buah penguaat inverting. Penguat pertama akan melipatkan keluaran tegangan menjadi 5 kilinya. Penguat invering berikutnya digunakan untuk merubah polaritas yang semula negatif menjadi polaritus positif. Penguatan diperlukan karena respon LM35 terhadap perubahan suhu relatif kecil yaitu 10 mV untuk setiap kenaikan I derajat Cclcius, 
sehingga bila suhu $100{ }^{\circ} \mathrm{C}$, maka regangan keluaran hanya $1 \mathrm{~V}$. Penguatan 5 kali dimaksudkan suhu mencapai 100 " C, maki keluaran tegangan $5 \mathrm{~V}$. dan ini merupakan batas maksimuin sinyal analog yang akan dibaca oleh modul akuisisi dan komunikasi data. Alasan lainnya adalah agar bila terjado penurunan tegangan akibat pemakaian kabel yang panjang tidak akan mempengaruhi hasil pembacaan. Sinyal keluatan sebagai masukan pada analog imput modul Arduno port A5.

Sensor keceputan angin digunakan untuk memberikan informasi kecepatan angin yang pada saat itu. Sensor terdiri dari baling-baling yang dikopel dengan poros dàn sebuah cakram. Pada gambar 4 diperlihatkan sistem mekanik. yang memungkinkan ditempatkannya sensor opio transistor. Baling-baling dengan dengan drameter $13 \mathrm{~cm}$. Gambar 8. Menunjukan opto transistor yang ditempatkan pada posisi cakram untuk mendapatkan informasi kecepatan angin. Informasi kecepatan angin berbanding lutus dengan banyaknya pulsa yang dihasilkan. Data jumlah pulsa selanjutnya sebagai masukan modul $F$ to $V$, selingga data input ke modul Arduino berupa tegangan $0-5$ Volt pada port A4

Pergaturan modul $F$ to $V$, adalah 1600 pulsa setara dengan 4 volt yang ekivalen dengan kecepatan angin $64 \mathrm{~km} / \mathrm{jam}$. Untuk mendapatkan nilai ini baling-baling dengan diameter $13 \mathrm{~cm}$ dalam satu puturan menempuh jarak panjang / keliling lingkaran dengan diameter $13 \mathrm{~cm}$ adalah $\mathrm{L}=3,14 \times \mathrm{d}$, sehingga kefiling $-3,14 \times 13=40,82 \mathrm{~cm}=0,4082 \mathrm{~m}$ dan dalam satu putaran terdapat 36 Tubang, yang akan menghasilkan 36 pulsa dalam satu putaran dengan lintasan 0,4082 meter.

Sensor arah angin difungsikan untuk memberikan informasi arah angin. Sensor terdiri dari potensio rotary $5 \mathrm{~K}$, yang dikopel dengan poros yang dihubungkan dengan plat almunium tipis yang difungsikan sebagai siripsirip. Bila sirip tertiup angin maka posisinya sejajar dengan arah angin dan potensio ratary akan mengikuti pergerakan arah angin tersebut. Prinsip rotary potensio adalah sebagai pembagi tegangan. dengan setting tegangan antura 0 sampai $4 \mathrm{~V}$, yang menunjukan arah angin antara 0 derajat sampai 359 derajat. Pengaturan tmtuk sensor ini adalah 0 derajat arali utara fegangan kelıaran 0,060 vollt, timut 90 derajat 1,45 volt. selatan 180 derajat keluaran tegangan 3 volt dan barat 270 detajat
Keluaran tegangan 4 volt. Keluaran tegangan ini sebagai masukan modul Arduno pada port A4

Secara umum, alat yang digunakan uniuk mengukur curab hujan disebut penakar bujan atau istilah lainnya rain gauge (penakar bujan). Satuan curah hujan yang umum digunakan oleh Badan Meteorologi, Klimatologi dan Geolisika adalah millimeter (mm). Jumlah curah hujan yang diukur sebenarnya adalah tebal atau tingginya permukaan ait hujan yang menutupi suanu area di permukaan bumi. Curah hujan 1 $\mathrm{mm}$ artinya dalam area $1 \mathrm{~m}^{2}$ (1 meter persegi) pada tempat yang datar tertampung air sefinggj $1 \mathrm{~mm}$ atau tertampung sebanyak I liter atau $1000 \mathrm{~m}]^{[7]}$.

Sensor curah hujan yang akan digmakan menggunakan jenis Tipping Bucket. Yang pada saat bucketnya saling beriungkit, secara elektrik terjadi kontak dan menghasilkan keluaran nilai curah hujan. Penakar hujan type tipping bucket, nilai curah hujannya tiap hucket berjungkit tidak sama, serla luas permukaan corongnya beragam teguntung dari merk pembuatnyat. Keluaran sinyal berupa data digital berupa pulsa, yang merepresentasikan banyaknya curah hujan yang ditakar.

Keterbatasan prasarana, sensor curah hujan banya disimulasikan dengan switch on off. Dengan pelipat informasi satu ketuk pulsa dilipatkan merijadi 4 pulsa dan akan mewakili sekitar $1 \mathrm{mun}^{3}$ air. Pengaturan modul $F$ to $V$ adalah malsinum 120 pulsa per detik dengan tegangan keluaran 4 Volt. Dengan pengaturan ini jumlah maksimum yang dapat dilakukan nengukuran adalah untuk $30 \mathrm{mrn}^{3}$ air dalam I detik Klasifikasi hujan lebat adalah $10-20 \mathrm{~mm}$ air untuk satu jam. yaitu dalam 1 jam tinggi air $10-20 \mathrm{~mm}$ untuk luasan $1000 \mathrm{~cm} \times 1000 \mathrm{~mm}$ atau volum air $10.000-20.000 \mathrm{~mm}^{3}$, dalam 1 jam atau 2,78$5,55 \mathrm{~mm}^{3}$ dalam satu detik. Sinyal keluaran legangan analog akan dimasukan ke modul arduino port $\mathrm{AZ}$.

\section{Akuisisi Dan Komunikasi Data}

Perangkat luuak yang digunakan untuk memprogram Arduino adalah Sketch versi 0.022. Perangkat lunak ini di upload ke modul Arduino untuk selanjutnya modul Arduino akan menangani perintah untuk melakukan pengambilan permbacaan data dari sesnsorsensor melalui analog input pada port $\mathrm{A} 1, \mathrm{~A} 2$. A3. A4, dan A5. Data basil pembacaan 
selanjutnya dikirim dengan format SMS melalui modul shield shield komunikasi GSM/GPRS lcomsat versi 1.10, dengan perintah AT Command. Gambar 4, menunjukan

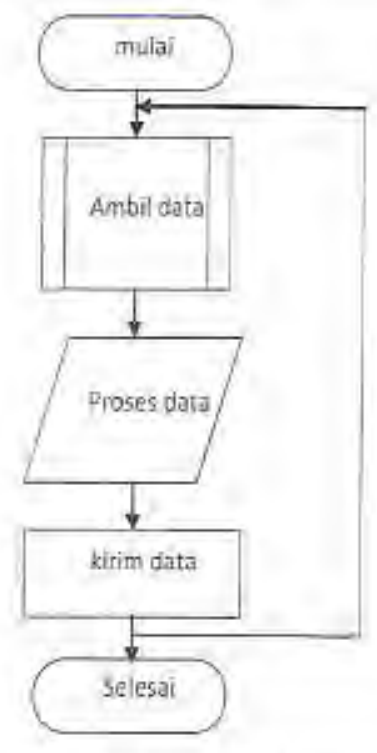

langkah akuisi data dari sensor untuk selanjutnya dikirim ke komputer informasi proses. Proses akuisisi dan pengiriman datanya seperti tertampil dalam Gambar 4.

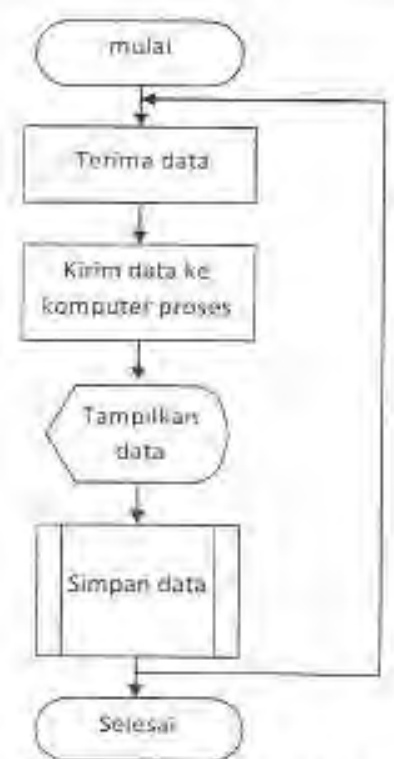

Gambar 4, a). Flowchart akuisi dan komunikasi data pada node, b) flowchart terima data dan tampilkan data pada komputer informasi proses

Program aplikasi Sketch digunakan untuk membuat program di modul Arduino yang digunakan untuk mengirimkan dan menerima data melalui layanan SMS. Penggalan list program pengiriman datanya adalah sebagai berikut :

void kirim paramatet_via_sms () 1

GPRS.print("AT+CMGF=1(r");

delay $(1000)$ :

GPRS.printin("AT+CMGS

$("-6287809267926$ " ");

delay $(1000)$;

$\mathrm{H} / \mathrm{isi}$ SMS

GPRS print("Node 001 :");

GPRS.print(" $\mid r ")$;

GPRS print(status batray);

GPRS.print (" $\left(r^{\prime \prime}\right)$;

GPRS.print(suhu):

GPRS.print(" II");

GPRS.print(arah_angin):

GPRS print(" $\left(\mathrm{r}^{\prime \prime}\right)$;

GPRS print(paparan radiasi);

GPRS.print(" $r ")$ :

GPRS.print(kecepatan_angin):

GPRS.print $\left("{ }^{\prime \prime}\right)$;

GPRS.println(curah_hujan);

GPRS.print(" $r ")$;
Serialprintln("SMS telah dikirim ke : +6287809267926"):

GPRS,println((char)26);

GPRS.println();

delay $(72000)$;

return :

;

Penggalan list program untuk penerimanya :

void Check_SMS();

if (Serial.available ()$>0$ )

3

while (Serial.available $)>0$ ) :

inSerial[i]-(Serial.reado): / baca data

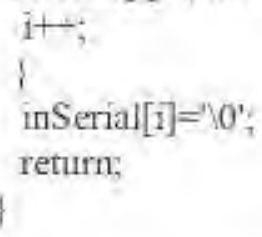

Pengaturan penyimpanan file dari pembacaan data menggunakan softrware Gobetwino. Software ini akan mengatur data serial yang dikirinkan dari modul penerima ke komputer untuk disimpan dalam bentok format file *CSV 


\section{HASIL DAN PEMBAHASAN}

Ilasil rancang bangun yang diimplementasikan setelah dilakukan integrasi dilakukan kalibrasi dan pengujian. Beberapa hal yang sudah dilakukan adalah integrasi untuk perangkat sensor cuaca dengan modul akuisisi dan komunikasi data. Gambar peralatan sistem yang dibangun dapat ditampilkan seperti pada Gambar 5, dan 6 .

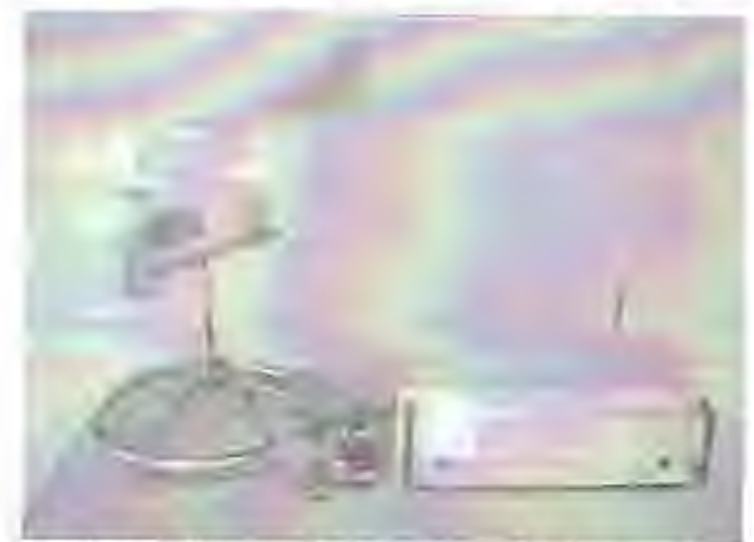

Gambar 5. Sistem akuisisi data dan komunikasi untuk node pengirim

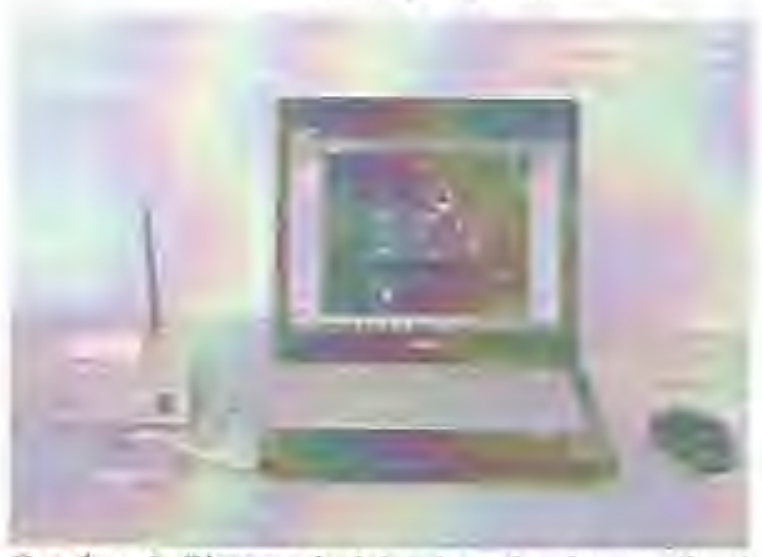

Gambar 6. Sistem akuisisi data dan komunikasi untuk komputer proses penerima

Data hasil pengukurannya adalah sebagai berikut file *.CSV, yang dapat dibuka dengan program aplikasi Microsoft Office Excel.

Hasil akuisi data setelab dilakukan pembacaan data akan dibandingkan dengan alat ukur lainnya untuk mengetahui prosentase kesalahan. Setelah dilakukan akuisisi data file *. CSV dilakukan editing dengan mengganti (.) dot menjadi komma (,) pada tampilan desimal agar bisa dilakukan perhitungan. $\mathrm{Hal}$ ini dilakukan karena pengaturan angka customisasi pada program Microsofi Excel pada komputer penulis menggunakan format Indonesia. Hasil data ditabelkan seperti pada tabel lampiran 1. Data hasil pengukuran.
Tampilan atau antar muka penyajian data dapat diperbaiki dengan menggunakan program berbasis Web. Tampilan yang berbasis Web dapat lebih informatif, dan dapat dijadikan web server, sehingga dapat dilakaukan pemantauan dari tempat lain atau perangkat lain.

Sistem yang dirancang memanfaatkan komunikasi GSM/GPRS, dengan melakukan pengiriman data yang memanfaatkan layanan SMS Jaringan komunikasi fihak ke tiga akan sangan mempengaruhi pengiriman data dari node ke modul penerima. Pengiriman data dilakukan setiap selang waktu 2 menit, sehingga untuk 24 jam diperlukan 720 kali SMS pengiriman data. Biaya operasional pengiriman data akan sangat tergantung dari tarif SMS yang dikenakan oleh operator, Saat ini tarif relatif murah karena banyak operator yang memberikan paket gratis 1000 SMS. Tabel 1. Data hasil pengukuran (lämpiran 1) dapat dilihat data hasil pengukuran.

Data hasil pengukuran selanjutnya dilakukan perbandingan dengan data yang diperoleh dari hasil pengukuran dengan perangkat lain. Pengukuran suhu untuk pembanding dilakukan dengan menggunakan termometer digital ruangan, yang diletakan berdekatan dengan sensor LM35. Hasilnya rerata selama berlangsung pengukuran adalah $30^{\circ} \mathrm{C}$. Pembanding untuk arah angin dilakukan dengan menggunakan kompas digital, yang diletakan sejajar dengan sirip-sirip arah angin, terukur pada kompas $228^{\circ}$. Kecepatan angin dibandingkan dengan perbandingan teori, yaitu dengan baling-baling diberi angin dengan menggunakan kipas angin, pulsa yang keluar dari sensor dilihat dan frekwensinya diukur dengan scoopmeter, hasilnya $205 \mathrm{~Hz}$. Bila 1 kali putaran per derik setara dengan jarak $0,4082 \mathrm{~m}$, maka $205 \mathrm{~Hz}$ setara dengan jarak 2,78 sn untuk setiap detiknya, atau 8,20 $\mathrm{km} / \mathrm{jam}$. Pengukuran curah hujan tidak dilakukan.

Perbandingan pengukuran paparan radiasi dilakukan dengan mengukur sample sumber radioaktif kaos lampu (mantle) yang dengan menggunakan surveymeter Thermo Scientific FAGG seri FH-40-GL. Hasil pengukuran dengan surveymeter menunjukan nilai $1,40 \mathrm{uSv} / \mathrm{jam}$.

Dari data hasil pengukuran tersebut dibandingkan dengan data dari pembacaan 
untuk diketahui besarnya kesalahan. Hasilnya dapat ditabelkan seperti tabel 2. di bawah.

$$
\begin{aligned}
& \text { Kes, relatif } \\
& =\frac{\text { Pemb. sistem }- \text { Pemb.Pemb }}{\text { Pemb. Pemb }} \times 100 \%
\end{aligned}
$$

Tabel 2. Hasil pembacaaan alat ukur dengan hasil pembacaan sistem pemantauan paparan radiasi terpadu.

\begin{tabular}{cccc}
\hline Parameter & $\begin{array}{c}\text { Pembacaan } \\
\text { Sistem }\end{array}$ & $\begin{array}{c}\text { Pembacaan } \\
\text { Pembanding }\end{array}$ & $\begin{array}{c}\text { Kesalahan } \\
\text { Relatif }\end{array}$ \\
\hline Suhu & 28,30 & 30,00 & 5,67 \\
Arah Angin & 300,02 & 228,00 & 7,15 \\
$\begin{array}{c}\text { Paparan } \\
\text { Radiasi }\end{array}$ & 1,54 & 1,40 & 10,00 \\
$\begin{array}{c}\text { Kecepatan } \\
\text { Angin }\end{array}$ & 8,41 & 8,20 & 2,56 \\
\hline \multicolumn{3}{c}{ Rerata kesalahan } & 6,34 \\
\hline
\end{tabular}

\section{KESIMPULAN}

Hasil menumjukan bahwa sistem yang dibangun berhasil dimplemantasikan untuk pemantauan paparan radiasi lingkungan terpadu secara on-line dan teal time untuk pemantauan jarak jauh. Sistem sangat tergantung kepada layanan jaringan komunikasi GSM/GPRS, katena pengiriman data dilakukan dengan layanan SMS. Tampilan sistem masih perlu perbaikan karena data masih disimpan dalam bentuk tabel dengan format file *.CSV, sehingga lebih user friendly dan informatif. Hasil pengujian dengan membandingkat dengan peralatan ukur standar dihasilkan kesalahan pembacaan subu 5,67\%, arah angin $7,15 \%$, paparan radiasi $10 \%$ dan kecepatan angin $2,56 \%$, rerata kesalahan 6,34 $\%$. Dengan kesalahan pembacaatn yang relatif masih tinggi perlu adanya perbaikan pada sistem terutama pada hardware.

\section{DAFTAR PUSTAKA}

1. Undang - Undang No 10 tahun 1997 rentang Ketenaganukliran.

2. Peraturan Pemerintah Peraturan Pemerintah No. 33 tahun 2007 tentang Keselamatan Sumber Radiasi Pengion dan Keamanan Sumber Radioaktif.

3. Komisi Proteksi Radiasi Kawasan Nuklir Serpong. "Pedoman Keselamatan dan Proteksi Radiasi Kawasan Nuklir Serpong Revisi I", BATAN. 2011.
4. Joẫo Valente, David Sanz, Antonio Barrientos . Jaime del Cerro, Ángela Ribeiro and Claudio Rossi, "An AirGround Wireless Sensor Network for Crop Monitoring", Sensors ISSN 1424-8220, Sensors 2011, 11, 6088-6108; doi: $10,3390 / \mathrm{s} 110606088$. www.mdpi.com/journal/sensors

5. Tokihiro FUK.ATSU, Masayuki HIRAPUJI, "Field Monitoring Using Sensor-Nodes with a Web Server", fournal of Robotics and Mechatronics Vol,17 No.2. $2005 \mathrm{pp} .164-172$.

6. Peter Rysavy, "GPRS to HSDPA and beyond, Rysavy Research. 2002.

7. http//dc237.4shared.com/doc/eNa8ASWa/ preview html, diakses 10 November 2012 


\section{Lampiran . Tabel data pengukuran}

\begin{tabular}{|c|c|c|c|c|c|c|c|c|c|}
\hline Waktu & & No datang. & Node & $\begin{array}{l}\text { Batray } \\
\%\end{array}$ & $\begin{array}{l}\text { Suhu } \\
{ }^{* C}\end{array}$ & $\begin{array}{l}\text { Arah } \\
\text { Angin } \\
*\end{array}$ & $\begin{array}{l}\text { Pap. } \\
\text { Rad } \\
\text { uSv/j }\end{array}$ & $\begin{array}{l}\text { Kec. } \\
\text { Angin } \\
\mathrm{km} / \mathrm{j}\end{array}$ & $\begin{array}{l}\text { Curah } \\
\text { Hujan } \\
\text { mm }\end{array}$ \\
\hline $\begin{array}{l}12 \text { Okt } \\
08: 40: 29\end{array}$ & 2013 & +6285927401223 & $\begin{array}{l}\text { Node } \\
001\end{array}$ & 100.00 & 28,44 & 300,02 & 1,50 & 8,35 & 0,00 \\
\hline $\begin{array}{l}12 \text { Okt } \\
08: 42: 29\end{array}$ & 2013 & +6285927401223 & $\begin{array}{l}\text { Node } \\
001\end{array}$ & 100,00 & 28,60 & 300,02 & 1,58 & 8,40 & 0,00 \\
\hline $\begin{array}{l}12 \text { Okt } \\
08: 44: 29\end{array}$ & 2013 & +6285927401223 & $\begin{array}{l}\text { Node } \\
001\end{array}$ & 100,00 & 28,06 & 300,02 & 1,63 & 8,50 & 0.00 \\
\hline $\begin{array}{l}12 \text { Okt } \\
08: 46: 29\end{array}$ & 2013 & +6285927401223 & $\begin{array}{l}\text { Node } \\
001\end{array}$ & 100,00 & 28,87 & 300,02 & 1,62 & 8,44 & 0,00 \\
\hline $\begin{array}{l}12 \text { Okt } \\
08: 48: 29\end{array}$ & 2013 & +6285927401223 & $\begin{array}{l}\text { Node } \\
001\end{array}$ & 100.00 & 27,56 & 300.02 & 1,40 & 8,38 & 0,00 \\
\hline $\begin{array}{l}12 \quad 0 k t \\
08: 50: 29\end{array}$ & 2013 & +6285927401223 & $\begin{array}{l}\text { Node } \\
001\end{array}$ & 100,00 & 28,99 & 300,02 & 1,54 & 8,48 & 0,00 \\
\hline $\begin{array}{l}12 \text { Okt } \\
08: 52: 29\end{array}$ & 2013 & +6285927401223 & $\begin{array}{l}\text { Node } \\
001\end{array}$ & 100,00 & 28,29 & 300,02 & 1.45 & 8,36 & 0.00 \\
\hline $\begin{array}{l}12 \text { Okt } \\
08: 54: 29\end{array}$ & 2013 & +6285927401223 & $\begin{array}{l}\text { Node } \\
001\end{array}$ & 100,00 & 28,43 & 300,02 & 1,61 & 8,34 & 0,00 \\
\hline $\begin{array}{l}12 \quad \mathrm{Okt} \\
08: 56: 29\end{array}$ & 2013 & +6285927401223 & $\begin{array}{l}\text { Node } \\
001\end{array}$ & 100,00 & 28,12 & 300,02 & 1,49 & 8.52 & 0.00 \\
\hline $\begin{array}{l}12 \quad \text { Okt } \\
08: 58: 29\end{array}$ & 2013 & +6285927401223 & $\begin{array}{l}\text { Node } \\
001\end{array}$ & 100,00 & 27,67 & 300,02 & 1,61 & 8,36 & 0,00 \\
\hline Rerata & & & & & 28,30 & 300,02 & 1,54 & 8,41 & 0,00 \\
\hline
\end{tabular}

